\title{
Biofloc technology on the intensive aquaculture of bronze corydoras ornamental fish Corydoras aeneus with different stocking densities
}

\author{
Teknologi bioflok pada budidaya intensif ikan hias koridoras \\ Corydoras aeneus dengan padat tebar berbeda
}

\author{
Iis Diatin ${ }^{1 *}$, Muhammad Agus Suprayudi', Tatag Budiardi ${ }^{1}$, Enang Harris ${ }^{1}$, \\ Widanarni $^{1}$
}

${ }^{1}$ Department of Aquaculture, Faculty of Fisheries and Marine Sciences, IPB University

(Bogor Agricultural University), West Java, Indonesia 16680

*Corresponding author: iisdiatin@yahoo.co.id

(Received January 4, 2018; Accepted June 17, 2019)

\begin{abstract}
Ornamental fish is non consumption fish which is an important source of Indonesian foreign exchange. The objective of this study is to analyze the productivity of bronze corydoras Corydoras aeneus ornamental fish through increased stocking density with biofloc technology. The average weight of the experimental corydoras was $0.61-$ $0.72 \mathrm{~g}$ with $2.32-2.40 \mathrm{~cm}$ standard length. This study used a randomized design method with biofloc technology treatment in 3000, 4500, and $6000 \mathrm{fish} / \mathrm{m}^{2}$ stocking densities. The results showed that the daily length and weightgrowth rate among treatments were not significantly different $(\mathrm{P}>0.05)$, while survival rate and the number of fish production on all treatments were significantly different $(\mathrm{P}<0.05)$. The water quality during the rearing period, such as temperature, $\mathrm{pH}$, alkalinity, ammonia, nitrite, and nitrate, were in a tolerable range for corydoras culture. The total suspended solids tended to be higher due to higher stocking density. The best productivity using biofloc technology obtained from $6000 \mathrm{fish} / \mathrm{m}^{2}$ stocking density.
\end{abstract}

Keywords: Biofloc technology, Corydoras aeneus, growth rate, stocking density, survival rate.

\begin{abstract}
ABSTRAK
Ikan hias merupakan produk perikanan non konsumsi yang menjadi sumber devisa Indonesia yang cukup penting. Penelitian ini bertujuan untuk menganalisis produktivitas ikan hias koridoras melalui peningkatan padat tebar dengan teknologi bioflok. Ikan yang digunakan adalah ikan hias koridoras Corydoras aeneus berbobot 0,61-0,72 g dan panjang baku 2,32-2,40 cm. Penelitian ini menggunakan rancangan acak lengkap dengan perlakuan teknologi bioflok pada padat tebar 3000, 4500, dan $6000 \mathrm{ekor} / \mathrm{m}^{2}$. Hasil penelitian menunjukkan bahwa laju pertumbuhan harian panjang dan bobot antar perlakuan tidak berbeda nyata $(P>0,05)$, sedangkan kelangsungan hidup dan jumlah produksi ikan pada semua perlakuan berbeda nyata $(\mathrm{P}<0,05)$. Nilai kualitas air selama pemeliharaan yakni suhu, $\mathrm{pH}$, alkalinitas, amonia, nitrit, dan nitrat yang berada pada kisaran yang cukup baik untuk budidaya ikan. Total padatan tersuspensi cenderung tinggi akibat dari semakin tinggi padat tebar. Produktivitas terbaik pada budidaya ikan koridoras dengan teknologi bioflok adalah pada padat tebar $6000 \mathrm{ekor} / \mathrm{m}^{2}$.
\end{abstract}

Kata kunci: Corydoras aeneus, kelangsungan hidup, padat tebar, pertumbuhan, teknologi bioflok 


\section{INTRODUCTION}

Indonesian ornamental fish production continues to increase for years. In 2016, Indonesian ornamental fish production had reached 1.3 billion fish and expected to reach 2.5 billion fish in the coming year (KKBK, 2017). Indonesia has proclaimed the national action plan of the ornamental fish industry to achieve this target (KKBK, 2017). Ornamental fish nowadays is a very prospective business with a great opportunity for development, thus has been grown into the fisheries industry in Indonesia. An effort to increased production was through the intensive fish culture system due to the limited natural resources such as land and water availability (Emerenciano et al., 2012; Gutierrez et al., 2016; Ahmad et al., 2017). This intensive culture system performed by maintaining fish production with high density (Avnimelech, 2012).

Corydoras is one of the export commodities that has been cultured in urban areas. The size of this fish is relatively small $(5-8 \mathrm{~cm})$ with an attractive shape, therefore it is possible to be maintained in the aquarium. There are approximately 170 species of corydoras fish widespread in the world (Tencatt et al., 2016). The low stocking density has been an issue that prevents the boost in the productivity. Performing an effective and efficient land and water usage, including increasing productivity and stocking density, could solve the problem. However, high stocking density causes declined water quality, resulting poor water environment, therefore requiring high control of environment, nutrients, predators, competitions, and disease agents (Appleford et al., 2012). One effort to reduce water quality degradation is applying the biofloc technology. This technology was generally applied to the intensive cultivation system with minimum or without water exchange (zero water discharge) and utilized the bacterial activity to degrade the organic material residue accumulation in water (Avnimelech, 2012). This technology increased production and contribute to sustainable fish culture support (Bossier \& Ekasari, 2017).

Biofloc technology had been applied in shrimp and fish culture. Nile tilapia culture with biofloc technology produced better growth rate than the control treatment (Widanarni et al., 2012; Luo et al., 2014; Long et al., 2015; Zhang et al., 2016; Pinho et al., 2017; Mansour \& Esteban, 2017) also improved the fingerling quality and production performance (Ekasari et al., 2015;
Perez-Fuentes et al., 2016; Alves et al., 2017; Garcia-Rios et al., 2019). Biofloc technology also increased the growth rate and fish feed efficiency in Labeo victorianus (Magondu et al., 2013), Pangasius catfish (Sutama et al., 2016), African catfish (Green et al., 2014; Bakar et al., 2015; Dauda et al., 2018a), and goldfish (Bakhshi et al., 2018). Biofloc technology enhances the survival rate of Pseudotropheus saulosi fish (Harini et al., 2016) and nile tilapia (Fleckenstein et al., 2018), as well as increasing nile tilapia immunity (Liu et al., 2018). Biofloc technology application in ornamental fish had been reported on goldfish (Faizullah et al., 2015; Wang et al., 2015), gibel carp Carassius auratus gibelio (Qiao et al., 2018), Pelteobagrus vachelli fish (Deng et al., 2018), and fin barb hybrid lemon fish (Dauda et al., 2018b). Previous experiment of the intensive corydoras fish culture with high density has been performed on the water exchange system with $30 \% /$ day and produces the best survival rate with $25 \mathrm{fish} / \mathrm{L}$ stocking density, equivalent to $3750 \mathrm{fish} /$ $\mathrm{m}^{2}$ (Diatin et al., 2014) and $4500 \mathrm{fish} / \mathrm{m}^{2}$ using 100\%/day water exchange (Diatin et al., 2015).

Based on the survey results on the corydoras ornamental fish culture center in Bogor and Depok, the ornamental fish farmers keep maintaining the application of low stocking density environment conditions (extensive system) with 80-400 fish/ $\mathrm{m}^{2}$, resulting in relatively low production of the fish. An experiment of biofloc technology application ornamental fish culture with high stocking density never performed. Therefore, this study aimed to analyze the productivity of bronze corydoras ornamental fish (C. aeneus) with biofloc technology on different stocking densities.

\section{MATERIALS AND METHODS}

\section{Fish rearing}

The fish used in this study was bronze corydoras fish ( $C$. aeneus) with $0.61-0.72 \mathrm{~g}$ weight and $2.32-2.40 \mathrm{~cm}$ standard length. The fish obtained from the hatchery in Bekasi, West Java. This study located in the laboratory of aquaculture production and management engineering, Department of Aquaculture, Faculty of Fisheries and Marine Sciences, IPB University Bogor. The experiment performed by a randomized design method with three treatments and three replications. Treatments given in this study were different stocking densities of corydoras fish on the fish culture using biofloc technology, namely $3000 \mathrm{fish} / \mathrm{m}^{2}$ (BFT3000), $4500 \mathrm{fish} / \mathrm{m}^{2}$ (BFT4500), 
Table 1. Daily length and weight growth rate, survival rate, and total production number of bronze corydoras fish on different stocking densities using biofloc technology

\begin{tabular}{lccc}
\hline \multirow{2}{*}{ Parameter } & \multicolumn{3}{c}{ Treatment } \\
\cline { 2 - 4 } & BFT3000 & BFT4500 & BFT6000 \\
\hline Daily weight growth rate (\%/day) & $1.02 \pm 0.06^{\mathrm{a}}$ & $0.96 \pm 0.03^{\mathrm{a}}$ & $0.97 \pm 0.08^{\mathrm{a}}$ \\
Daily length growth rate (\%/day) & $0.30 \pm 0.01^{\mathrm{a}}$ & $0.30 \pm 0.01^{\mathrm{a}}$ & $0.29 \pm 0.01^{\mathrm{a}}$ \\
Survival rate $(\%)$ & $67.50 \pm 2.20^{\mathrm{c}}$ & $62.04 \pm 1.60^{\mathrm{b}}$ & $50.42 \pm 3.00^{\mathrm{a}}$ \\
Total production $\left(\right.$ fish $\left./ \mathrm{m}^{2}\right)$ & $2025 \pm 66^{\mathrm{c}}$ & $2792 \pm 72^{\mathrm{b}}$ & $3025 \pm 180^{\mathrm{a}}$ \\
\hline
\end{tabular}

*The same letter on the same line shows insignificant different value with 5\% confidence level (Duncan test)

Table 2. The range value of DO, temperature, and $\mathrm{pH}$ during the rearing period of bronze corydoras culture using biofloc technology with different stocking densities

\begin{tabular}{cccc}
\hline Parameter & BFT3000 & BFT4500 & BFT6000 \\
\hline DO $(\mathrm{mg} / \mathrm{L})$ & $4.2-5.9$ & $4.1-5.9$ & $4.2-5.6$ \\
Temperature $\left({ }^{\circ} \mathrm{C}\right)$ & $25.2-26.6$ & $25.3-26.6$ & $25.3-26.5$ \\
$\mathrm{pH}$ & $7.7-8.7$ & $7.6-8.8$ & $7.5-8.4$ \\
\hline
\end{tabular}

and $6000 \mathrm{fish} / \mathrm{m}^{2}$ (BFT6000), referred to Diatin et al. (2015). The fish density on each aquarium treatment was 120, 180, and 240 fish.

The fish placed on a pre-treatment condition of 10 days emplacement in aquarium sized 100 $\mathrm{cm} \times 50 \mathrm{~cm} \times 40 \mathrm{~cm}$ with $1500 \mathrm{fish} / \mathrm{m}^{2}$. At the same time, the fish were fed sludge worm with ad libitum method during this adaptation period. Sequentially, the ornamental fish were kept for 40 days in aquarium sized $20 \mathrm{~cm} \times 20 \mathrm{~cm} \times 20$ $\mathrm{cm}$, then aerated and filled with water as high as $15 \mathrm{~cm}$. Water volume total of each aquarium was $6 \mathrm{~L}$. Biofloc technology used $\mathrm{C} / \mathrm{N}$ ratio 12 with molasses as the carbon source $(45.27 \%$ carbon level). Molasses were given daily on 2 hours after feeding. $\mathrm{N}$ content in feed and molasses requirements on each day was calculated based on the formula of De Schryver et al. (2008).

This fish fed of live sludge worm containing $8.12 \%$ protein, $4.26 \%$ lipid, $0 \%$ crude fiber, $82.29 \%$ water, $1.97 \%$ ash, and $4.26 \%$ NFE (nitrogen free extract). Feed was given twice a day at 07.00 and 18.00 GMT+7 as much as 5\% of fish biomass per day. Water was added every two weeks on all treatments to maintain the water quality and reduced water volume due to evaporation.

\section{Parameters}

Growth sampling performed every ten days by measuring the fish length and weight from 30 fish on each treatment. Survival rate sampling performed concurrently with growth sampling by calculating the total number of living fish. Water quality was measured daily during the fish rearing containing dissolved oxygen, $\mathrm{pH}$, and temperature. Water quality measurement performed in the morning (at 07.00 GMT+7). The measurement of ammonia, nitrite, nitrate, alkalinity, TSS (total suspended solid), VSS (volatile suspended solid), and floc volume performed weekly. Bacterial abundance and content in water and fish intestinal fish determined at the beginning and end of the study.

The fish weight was measured using a $200 \mathrm{~g}$ capacity digital scale, while the fish length was measured using vernier caliper. Growth and survival rates were calculated using Huisman (1987) formula. Temperature measurement used thermometers, dissolved oxygen used DO meter, $\mathrm{pH}$ used $\mathrm{pH}$ meter, and turbidity level used Turbidimeter. Alkalinity was measured using a volumetric method, whereas TSS and VSS value was measured using the gravimetric method. The measurements of ammonia, nitrite, and nitrate were performed using spectrophotometer with APHA (1989) method. The floc volume was measured using $15 \mathrm{ml}$ conical tube and calculated based on Avnimelech (2012) formula. Bacterial abundance was analyzed using the spread plating method. Bacteria that dominantly grew on each sample were identified based on the physiology and biochemistry characteristics (Cowan \& Steel, 1974).

\section{Data analysis}

Data on the observation results were presented based on the average value and standard deviation. Data were processed and analyzed using Ms. Excel 2007 software and SPSS 20.0. The daily 


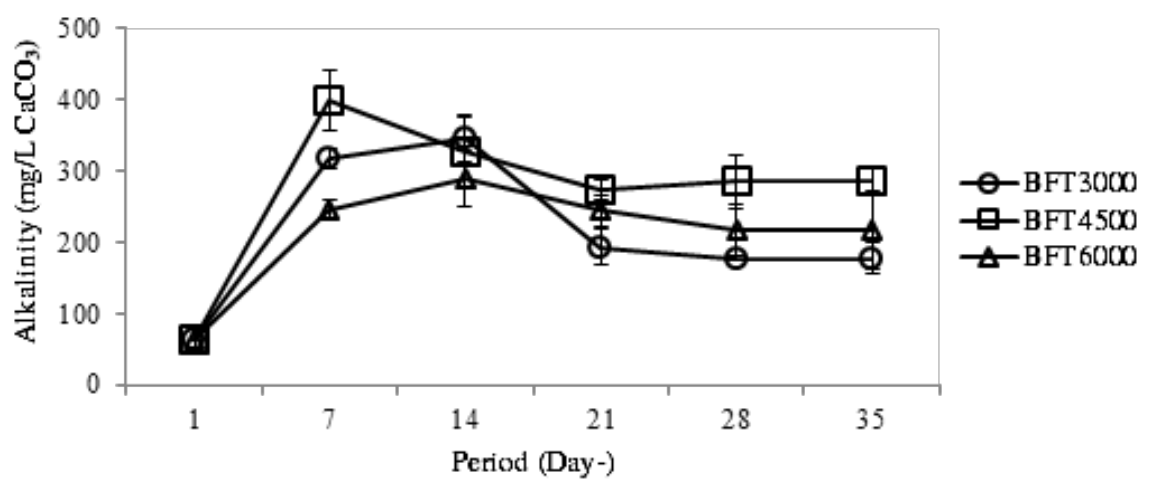

Figure 1. The alkalinity level of water media for bronze corydoras culture using biofloc technology with different stocking densities.

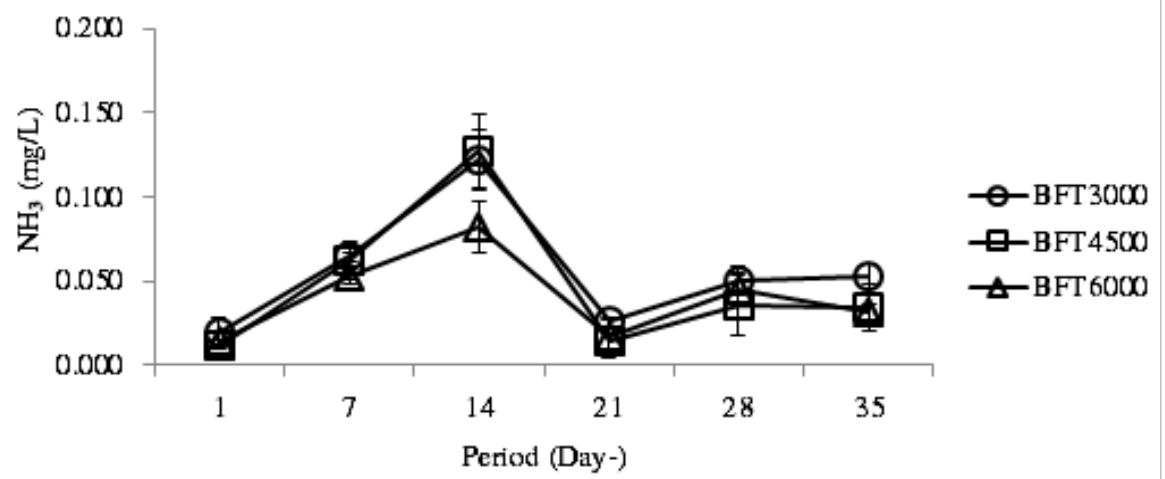

Figure 2. The ammonia $\left(\mathrm{NH}_{3}\right)$ level of water media for bronze corydoras culture using biofloc technology with different stocking densities.

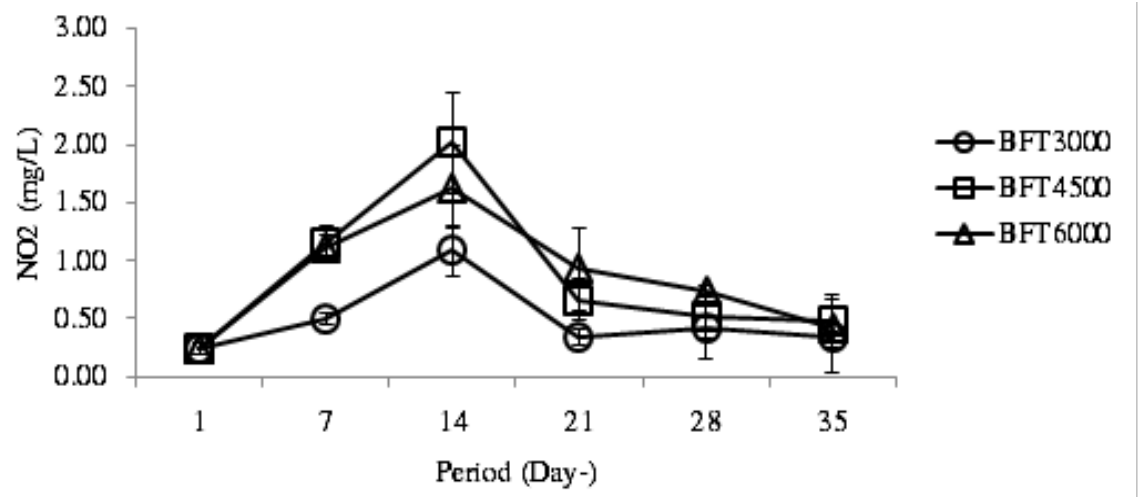

Figure 3. The nitrite $\left(\mathrm{NO}_{2}\right)$ level of water media for bronze corydoras culture using biofloc technology with different stocking densities.

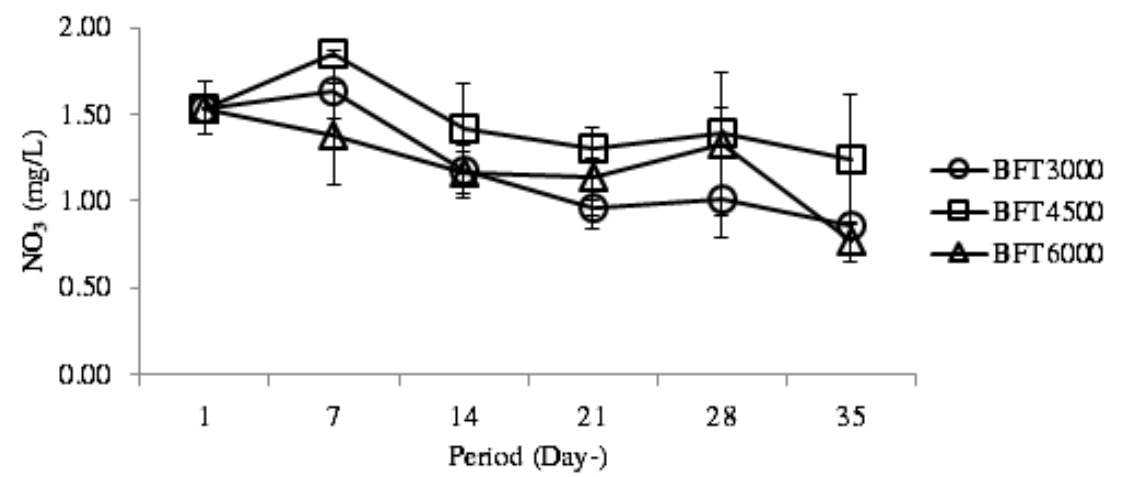

Figure 4. The nitrate $\left(\mathrm{NO}_{3}\right)$ level of water media for bronze corydoras culture using biofloc technology with different stocking densities. 


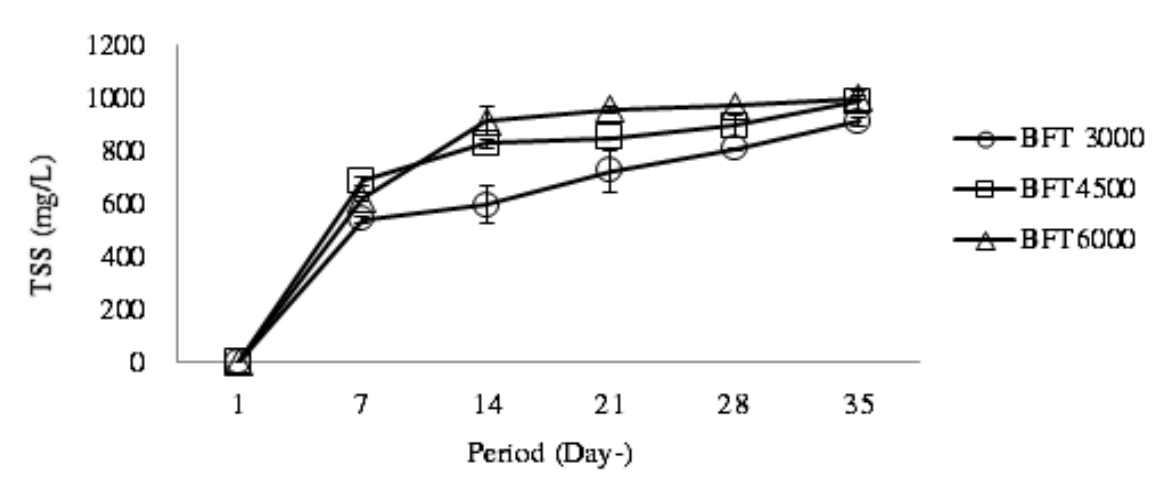

Figure 5. The TSS (total suspended solids) level of water media for bronze corydoras culture using biofloc technology with different stocking densities.

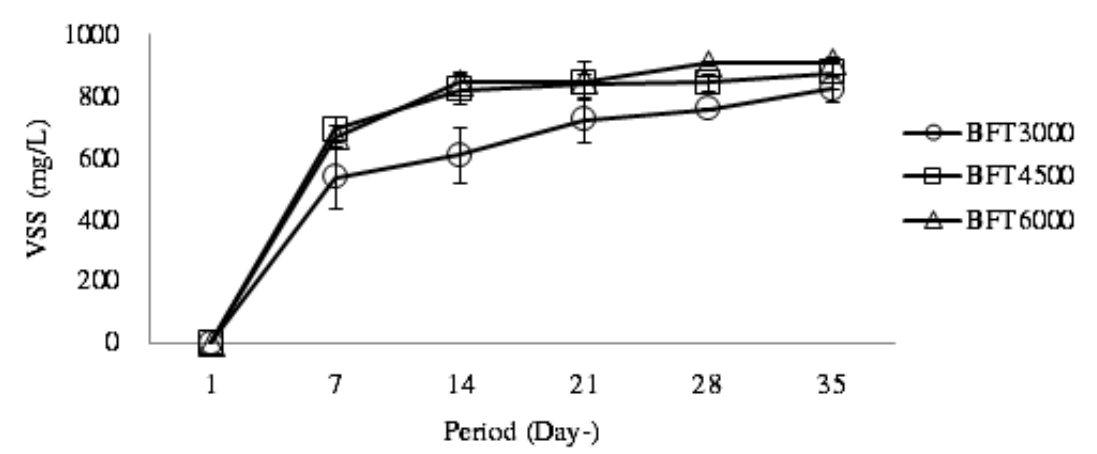

Figure 6. The VSS (volatile suspended solids) level of water media for bronze corydoras culture using biofloc technology with different stocking densities.

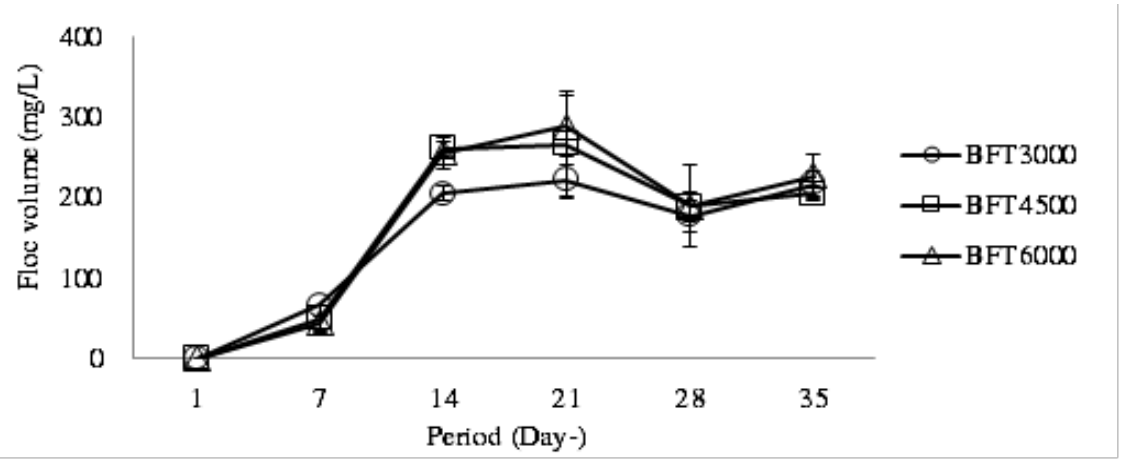

Figure 7. The floc volume of water media for bronze corydoras culture using biofloc technology with different stocking densities.

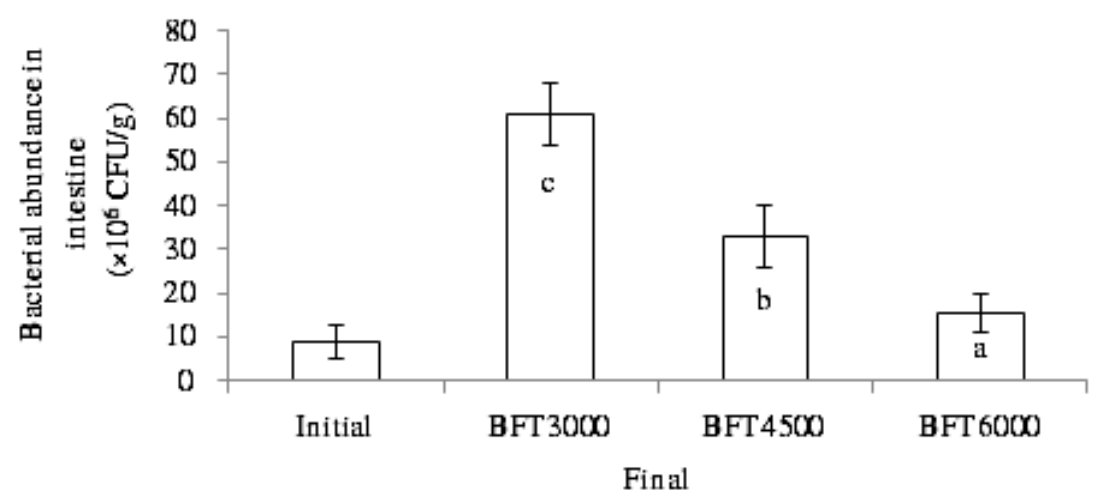

Figure 8. Bacterial abundance on the intestine of bronze corydoras fish on biofloc technology with different stocking densities. 
Table 3. Bacterial type on the rearing media and intestine of bronze corydoras fish on the biofloc technology with different stocking densities

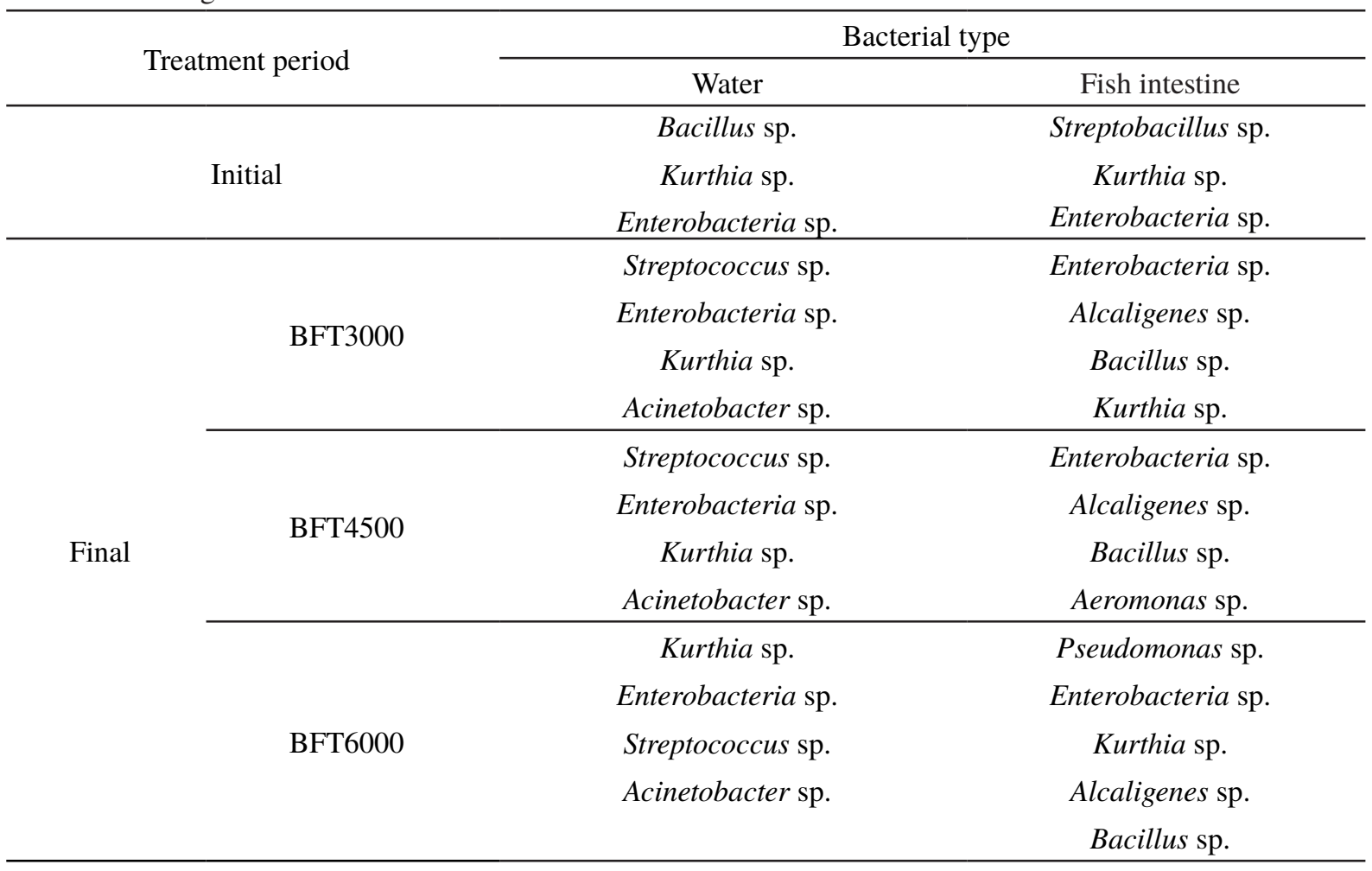

growth, survival, and fish production rate were analyzed using analysis of variance (ANOVA) at $95 \%$ confidence interval, then continued with Duncan significant different test.

\section{RESULT AND DISCUSSION}

\section{Result}

Daily growth rate

The daily weight and length growth rate, as well as survival rate and total production of bronze corydoras fish on each treatment presented in Table 1.

Statistical analysis results (Table 1) indicated that the value of daily length and weight growth rate on all treatments were insignificantly different $(\mathrm{P}>0.05)$. However, the survival rate of bronze corydoras ornamental fish produced significantly different value on each treatment. The highest survival rate showed in $3000 \mathrm{fish} / \mathrm{m}^{2}$ stocking density, however, the highest total production showed in $6000 \mathrm{fish} / \mathrm{m}^{2}$ stocking density.

The daily water quality parameters measured were DO, temperature, and $\mathrm{pH}$ which are presented in Table 2. Other water quality parameters, such as alkalinity, ammonia, nitrite, and nitrate, presented in Figures 1-4.

The study result showed that the TSS and VSS value increased after $14^{\text {th }}$ days of rearing, while the floc volume extremely increased on $21^{\text {st }}$ days of rearing, as presented in Figure 5, 6, and 7 . The bacterial abundance level and the types were shown in the following chart (Figure 8). Bacterial on the rearing media using biofloc technology obtained five dominant types, while seven dominant types were obtained from the bronze corydoras fish intestine, as presented on Table 3.

\section{Discussion}

The daily length and weight growth rate (Table 1) among treatments were insignificantly different as the stocking density of bronze corydoras fish culture using biofloc technology did not affect the length and weight growth of fish. This condition suggests that bronze corydoras fish on all treatments acquired adequate feed intake. Corydoras fish usually form flock (school and shoal) to find food and produced a sound to draw attention so that when fish are schooling, the feed will be utilized efficiently by all fish (Ithurralde $e t$ al., 2014; Hadjiaghai \& Ladich, 2015).

High stocking density caused limited fish movement, causing space competition, increased aggressiveness among fish, and cannibalism that leads to death (Manley et al., 2014; Barros et al., 2019; Xi et al., 2017). Fish aggressiveness will result in increased friction among fins and movements that will injure other fish. Fish aggressiveness will also produce a dominant fish in their group, making the lost fish will divide, 
stressed, then dead (Huntingford \& Damsgard, 2012). The survival rate of bronze corydoras fish using biofloc technology yield a significant difference among treatments. The highest survival rate was found on $3000 \mathrm{fish} / \mathrm{m}^{2}$ stocking density, while the lowest found on $6000 \mathrm{fish} / \mathrm{m}^{2}$ stocking density (Table 1). Higher stocking density of fish cultured with biofloc technology results in a low survival rate. This result was in line with Magondu et al. (2013) on Labeo victorianus, Widanarni et al. (2012) on red tilapia, Schveitzer et al. (2013) on vaname shrimp, and Ardiansyah and Fotedar (2016) on snapper juvenile. However, the total production of bronze corydoras fish produced at the end of the study showed that the highest total production discovered on a very high intensive treatment (BFT6000). This was presented by the total production of fish at the end of the study on all treatments, i.e., BFT3000, BFT4500, and BFT6000 with $2025 \pm 66 \mathrm{fish} / \mathrm{m}^{2}, 2792 \pm 72 \mathrm{fish} /$ $\mathrm{m}^{2}$, and $3025 \pm 180 \mathrm{fish} / \mathrm{m}^{2}$ respectively (Table 1 ).

Increased stocking density in an intensive culture can lead to decreased quality of culture water and increased waste metabolites in the culture environment (Emerenciano et al., 2012; Luo et al., 2013). C. aeneus live optimally at 24$28^{\circ} \mathrm{C}$ temperature, $\mathrm{pH}$ 6-7 (Alderton, 2008), $\mathrm{pH}$ 6.2-8.5 (Mahapatra \& Dutta, 2014), and about 3 $\mathrm{mg} / \mathrm{L}$ DO (Boyd, 2010). Corydoras fish lives in the water base (Davis et al., 2014) with additional breathing apparatus in intestines, making it more tolerant to low oxygen level (Satora et al., 2017). The temperature level during corydoras culture was $25.2-26.6^{\circ} \mathrm{C}$, $\mathrm{pH} 7.5-8.8$, and $\mathrm{DO} 4.1-5.6$ $\mathrm{mg} / \mathrm{L}$ (Table 2), which was still in the tolerance for corydoras fish culture.

Biofloc system can cause alkalinity fluctuation (Furtado et al., 2015). This study showed increased alkalinity value on the $7^{\text {th }}$ day of rearing, then stabilized on the $21^{\text {st }}$ day until the end of the study (Figure 1). The same result found on the vaname shrimp with biofloc technology, showing the relatively stable alkalinity value after the $21^{\text {st }}$ day (Furtado et al., 2015). Corydoras fish prefer water with a neutral or slightly alkaline condition (Alderton, 2008). Previous studies with biofloc technology in vaname shrimp acquired alkalinity value reached $300 \mathrm{mg} / \mathrm{L}$ (Furtado et al., 2015) and $200 \mathrm{mg} / \mathrm{L}$ (Maica et al., 2018), then goldfish reached $260 \pm 4.2 \mathrm{mg} / \mathrm{L}$ (Faizullah et al., 2015).

Ammonia concentration increased on $14^{\text {th }}$ day, then decreased at the end of the study with the highest value was found on BFT4500 treatment of $0.128 \pm 0.022 \mathrm{mg} / \mathrm{L}$. However, the overall value could still within the range of toleration of corydoras fish. The ammonia reduction on African catfish (Clarias gariepinus) culture with $\mathrm{C} / \mathrm{N} 15$ began on $9^{\text {th }}$ to $12^{\text {th }}$ day, until $30^{\text {th }}$ day reaching $98.7 \%$, while $\mathrm{C} / \mathrm{N} 10$ increased ammonia reduction occurred from $18^{\text {th }}$ to $21^{\text {st }}$ day, reaching 98.51\% (Bakar et al., 2015). This study used C/N 12 ratio, therefore, the increasing ammonia value to the maximum on the $14^{\text {th }}$ day was most likely occured due to the conversion of ammonia by the heterotrophic bacteria, which performed from the $14^{\text {th }}$ day until the end of the study.

Ammonia is generally toxic to fish (Shiwanand \& Tripathi, 2013) when reaching out of $1.5 \mathrm{mg} / \mathrm{L}$ (Yusoff et al., 2011; Avnimelech, 2012). The concentration of $2 \mathrm{mg} / \mathrm{L}$ nitrite causes the slow growth rate of fish and $4 \mathrm{mg} / \mathrm{L}$ causes acute death (Yusoff et al., 2011). Acute concentration of nitrite in yellow catfish (Pelteobagrus fulvidraco) sized $0.029 \pm 0.049 \mathrm{~g}$ was $8.74 \mathrm{mg} / \mathrm{L}$ (Zhang et al., 2012), while nitrite content of $3.92 \mathrm{mg} / \mathrm{L}$ lowered the daily growth rate below $2 \%$ in african catfish (C. gariepinus) (Roques et al., 2015). Nitrates are relatively non-toxic to fish, but the concentrations of $75 \mathrm{mg} / \mathrm{L}$ will reduce the growth rate on fish juvenile (Yusoff et al., 2011). The concentration of lethal ammonia $\left(\mathrm{LC}_{10}\right)$ is $0.120 \mathrm{mg} / \mathrm{L}$ and $\mathrm{LC}_{50}$ is $0.146 \mathrm{mg} / \mathrm{L}$ for corydoras fish (Souza-Bastos et al., 2017), while nitrite concentration reaches $0.4 \mathrm{mg} / \mathrm{L}$ and nitrate $2.5 \mathrm{mg} / \mathrm{L}$ (Casenave et al., 2005). Corydoras fish includes in the ornamental catfish with ammonia-tolerant (Santos \& Esteves, 2015; Souza-Bastos et al., 2017), whereby the concentration of ammonia, nitrite, and nitrate acquired in this study were still in the tolerance range for corydoras culture.

The existence of biofloc was detected through TSS, VSS, and floc volume value (De Schryver et al., 2008; Avnimelech, 2012). One main character of biofloc system was high suspended solid value as an indicator of the high water suspended organic material (Crab et al., 2012). The TSS value range recommended for biofloc technology should be 200-1000 mg/L (De Schryver et al., 2008). Tilapia culture obtained TSS value with $643 \mathrm{mg} / \mathrm{L}$ (Avnimelech, 2012) and 421-457 mg/L in shrimp cultivation integrated with tilapia (Poly et al., 2019). Moreover, channel catfish (Ictalurus punctatus) culture produced the lowest survival rate with TSS value of $759.4 \pm 44.5 \mathrm{mg} / \mathrm{L}$ (Green et al., 2014). South American catfish (Rhamdia quelen) acquired TSS value with $425 \pm 2.38$ $\mathrm{mg} / \mathrm{L}$ (Rocha et al., 2017) reaching $1000 \mathrm{mg} / \mathrm{L}$ (Poly et al., 2015), while on African catfish (C. gariepinus) reached $701.25 \pm 48.17 \mathrm{mg} / \mathrm{L}$ (Dauda et al., 2018b). The results of this study showed 
that the highest TSS value (Figure 5) found in BFT6000 treatment. The height of suspended solid causes the gill interference that causes the fish to breathe hard and lead to death, therefore lowering the survival rate. According to Schveitzer et al. (2013), gill disturbances in vaname shrimp due to high suspended solid (800-1000 mg/L TSS value) can reach $60 \%$. VSS is used to measure bacterial biomass (De Schryver et al., 2008; Avnimelech, 2012). The heterotrophic system generates approximately $406 \mathrm{VSS} / \mathrm{kg}$ feed with a 35\% feed protein level (Ebeling \& Timmons, 2008). Other studies on vaname shrimp resulted VVS value was $408 \mathrm{mg} / \mathrm{L}$ (Kim et al., 2013) and on channel catfish (I. punctatus) was $641 \pm 42.9$ $\mathrm{mg} / \mathrm{L}$ (Green et al., 2014). The value of VSS on all treatments at the end of the study ranged 823 $\pm 3.28-910 \pm 4.24 \mathrm{mg} / \mathrm{L}$ (Figure 6), showing heterotrophic bacterial biomass on this study.

Fish can utilize biofloc as a protein source and feed for growth enhancement, however the certain types of fish in biofloc density should be at the optimum range due to fish feeding behavioral interference, whether given too much biofloc and cause fish stress (Bakar et al., 2015). Biofloc is an aggregate composed of floc-forming bacteria, filamentous bacteria, microalgae (phytoplankton), protozoa, organic matter, bacterial eaters (Avnimelech, 2012), zooplankton, fungi and viruses (Browdy et al., 2012). Corydoras fish can utilize biofloc as feed evidenced from the bacterial abundance as one of the forming floc aggregates in the fish intestine. The bacterial abundance in the fish intestine at the end of the study increased compared to the initial period as there was an improved bacterial abundance occurred on BFT3000 treatment, reaching six times (Figure 8). The utilization of biofloc as feed sources depends on the species, feeding habits, size, floc density, and floc size (Avnimelech, 2012). The result of this study showed that floc formed from $7^{\text {th }}$ day, then the floc volume increased until $14^{\text {th }}$ day (Figure 7). The floc volume after the $14^{\text {th }}$ day ranged between $206-289 \mathrm{~mL} / \mathrm{L}$, indicating floc is available in the water utilized as feed source by corydoras fish.

The bacterial density in the fish intestine during the initial period was $8.9 \pm 3.81 \times$ $10^{6} \mathrm{CFU} / \mathrm{g}$, then increased on each treatment differently (Figure 8). Increased bacterial density in fish intestine suggests that corydoras fish can utilize biofloc as a feed source. The bacterial density in BFT3000 treatment increased almost six times, BFT4500 increased almost three times, and BFT6000 increased about 1.5 times. This condition suggests that biofloc can be utilized as a feed source to support the growth of corydoras fish.

Bacterial type in biofloc rearing media (Table 3) obtained five types of dominant bacteria, namely Bacillus sp., Kurthia sp., Enterobacteria sp., Streptococcus sp., and Acinetobacter sp., while seven types of dominant bacteria found in the fish intestine, namely Bacillus sp., Kurthia sp., Enterobacteria sp., Alcaligenes sp., Streptobacillus sp., Aeromonas sp., and Pseudomonas sp. Five types of bacteria found in this study was the same as obtained by Widanarni et al. (2013) on red tilapia culture with biofloc technology, discovering six types of dominant bacteria, namely Bacillus sp., Kurthia sp., Listeria sp., Alcaligenes sp., Enterobacteria sp., and Acinetobacter sp. The biofloc technology could increase the probiotic bacterial abundance that was beneficial for fish growth and immunostimulatory agent (Gutierrez et al., 2016; Ahmad et al., 2017). The results of the bacterial identification found in this study generally are heterotrophic bacteria. Heterotrophic bacteria grow faster and produce more than 40 times bacterial biomass than autotrophic bacteria (Ebeling \& Timmons, 2008), therefore decreased water quality problems due to high density can be more quickly solved by heterotrophic bacteria role in biofloc technology.

\section{CONCLUSION}

Bronze corydoras ornamental fish culture using biofloc technology can be applied with $6000 \mathrm{fish} / \mathrm{m}^{2}$ stocking density.

\section{REFERENCES}

Ahmad I, Rani AMB, Verma AK, Maqsood M. 2017. Biofloc technolog: an emerging in aquatic animal healthcare and nutrition. Aquaculture International 25: 1215-1226.

Alves GFO, Fernandes AFA, Alvarenga ER, Turra EM, Sousa AB, Teixeira EA. 2017. Effect of the transfer at different moments of juvenile nile tilapia Oreochromis niloticus to the biofloc system in formation. Aquaculture 479: 564-570.

[APHA] American Public Health Association. 1989. Standard Methods for the examination of Water and Wastewater. 20 ${ }^{\text {th }}$ ed. Washington DC (US): APPHA.AWWA.WPCF.

Alderton. D. 2008. Encyclopedia of Aquarium \& Pond Fish. US. Dorling Kindersey Publishing. 
Appleford P, Lucas JS, Southgate PC. 2012. General Principles. Di dalam: Lucas JS and Southgate PC, editor. Aquaculture: Farming Aquatic Animals and Plants. Second edition. US. Willey-Blackwell.

Ardiansyah, FotedarR. 2016. Water quality, growth and stress responses of juvenile barramundi (Lates calcalifer Bloch), reared at four different densities in integrated recirculating aquaculture systems. Aquaculture 458: 113120.

Avnimelech Y. 2012. Biofloc Technology. A Practical Guide Book. Second Edition. Louisiana (US). World Aquaculture Society.

Bakar NSA, Nasir NM, Lananan F, Hamid SHA, Lam SS, Jusoh A. 2015. Optimization of C/N ratios for nutrientremoval in aquaculture system culturing African catfish Clarias gariepinus utilizing bioflocs technology. International Biodeterioration \& Biodegradation 102: 100106.

Bakhshi F, Najdegerami EH, Manaffar R, Tukmechi A, Farah KR. 2018. Use of different carbon sources for the biofloc system during the grow-out culture of common carp (Cyprinus carpio L) fingerlings. Aquaculture 484: 259-267.

Barros IBA, Villacarta-Correa MA, Canvalho TB. 2019. Stocking density and water temperature as modulators of aggressiveness, survival and zootechnical performance in matrinxa larvae, Brycon amazonicus. Aquaculture 502: 378383.

Bossier P, Ekasari J. 2017. Biofloc technology application in aquaculture to support sustainable development goals. Microbial Biotecnology: 1-5.

Boyd C. 2010. Dissolved Oxygen Consentration in pond aquaculture. Global Aquaculture Advocate 1: 40-41.

Browdy CL, Ray AJ, Leffler JW, Avnimelech Y. 2012. Biofloc-based aquaculture systems. In: Tidwell JH, editor. Aquaculture Production Systems. US. Willey Blackwell.

Casenave J, Wunderlin DA, Hued AC, Bistoni MLA. 2005. Haematological parameters in a neotropical fish, Corydoras paleatus (Jenyns, 1842) (Pisces, Callichthydae, captured from pristine and polluted water. Hydrobiologia 537: 25-33.

Crab R, Defoirdt T, Bossier P, Verstraete W. 2012. Biofloc technology in aquaculture: Beneficial effects and future challenges. (review). Aquaculture 356-357: 351-356.
Cowan S, Steel K. 1974. Manual for the identification of medical bacteria second edition. Cambrige. Cambrige University Press.

Dauda AB, Romano N, Ebrahimi M, The JC, Ajadi A, Chong CM, Karim M, Natrah I, Kamarudin MS. 2018a. Influence of carbon/ nitrogen ratios on biofloc production and biochemical composition and subsequent effects on the growth, physiological status and disease resistence of African catfish Clarias gariepinus cultured in glycerol-based biofloc systems. Aquaculture 483: 120-130.

Dauda AB, Romano N, Chen WW, Natrah I, Kamarudin MS. 2018b. Differences in feeding habits influence the growth performance and feeding efficiences of African catfish Clarias gariepinus and lemon fin barb hybrid (Hypsibarbus wetmorei $\times$ Barboides gonionotus) in a glycerol-based biofloc technology system versus a recirculating system. Aquacultural Engineering 82: 31-37.

Davis VA, Holbrook RI, Schumacher S, Guilford T, Perera TB. 2014. Three-dimensional spatial cognition in a benthic fish, Corydoras aeneus. Behavioural Processes 109: 151-156.

De Schryver P, Crab R, Defoirdt T, Boon N, Verstraete W. 2008. The basics of bio-flocs technology: The added value for aquaculture. Aquaculture 277: 125-137.

Deng M, Chen J, Gou J, Hou J, Li D, He X. 2018. The effect of different carbon sources on water quality, microbial community and structure of biofloc systems. Aquaculture 482: 103-110.

Diatin I, Harris E, Suprayudi MA, Budiardi T. 2014. The growth and survival rate of ornamental fish bronze corydoras Corydoras aeneus (Gill, 1858) in high density cultured. Jurnal Iktiologi Indonesia 14: 123-134.

Diatin I, Suprayudi MA, Budiardi T, Surawidjaja EH, Widanarni. 2015. Intensive culture of corydoras ornamental fish Corydoras aeneus: evaluation of stocking density and water exchange. AACL Bioflux 8: 975-987.

Ebeling JM, Timmons MB. 2008. Carbon: nitrogen balance impacts nitrogen removal processes in microbial-based aquaculture systems. Global Aquaculture Advocate 11: 38-40.

Ekasari J. Rivandi DR, Firdausi AP, Surawidjaja EH, Zairin Jr M, Bossier P, De Schryver P. 2015. Biofloc technology positively affects Nile tilapia Oreochromis niloticus larvae performance. Aquaculture 441: 72-77. 
Emerenciano M, Ballester ELC, Cavalli RO, Wasielesky W. 2012. Biofloc technology application as a food source in a limited WAter exchange nursery system for pink shrimp Farfantepenaeus brasiliensis (Latreille, 1817). Aquaculture Research 43: 447-457.

Faizullah M, Rajagopalsamy CBT, Ahilan B, Francis T. 2015. Impact of biofloc technology on the growth of goldfish young ones. Indian Journal of Science and Technology 8: 2-8.

Fleckenstein LJ, Tierney TW, Ray AJ. 2018. Comparing biofloc, clear-water, and hybrid recirculating nursery systems (Part II): Tilapia Oreochromis niloticus production and water quality dynamics. Aquacultural Engineering 82: 80-85.

Furtado PS, Poersch LH, Wasielesky JrW. 2015. The effect of different alkalinity levels on Litopenaeus vannamei reared with biofloc technology (BFT). Aquaculture International 23: 345-358.

Garcia-Rios L, Miranda-Baeza A, CoelhoEmernciano MG, Huerta-Rabago,JA, OsunaAmarillas P. 2019. Biofloc technology (BFT) applied to tilapia fingerlings production using different carbon resources: Emphasis on commercial applications. Aquaculture 502: 26-31.

Green BW, Schrader KK, Perschbacher. 2014. Effect of stocking biomass on solids, phytoplankton communities, common offflavors, and production parameters in a channel catfish biofloc technology production system. Aquaculture Research 45: 1442-1458.

Gutierrez SM, Desta MCM, Partida AH, Mejia JS, Oca GARM. 2016. Effect two carbon sources ini microbial abundance in a biofloc culture system with Oreochromis niloticus (Linnaeus, 1758). International Journal of Fisheries and Aquatic Studies 4: 412-427.

Hadjiaghai O, Ladich F. 2015. Sex-specific differences in agonistic behavior, sound production and auditory sensitivity in the Callichthyid armoured catfish Megalechis thoracata 10: 1-25.

Harini C, Rajagopalasamy CBT, Kumar JSS, Santhakumar R. 2016. Role of biofloc in the growth and survival of blue morph, Pseudotropheus saulosi. Indian Journal of Science Technology 9: 1-7.

Huisman EA. 1987. The principles of fish culture production. Departement of Fish and Fisheries, Wageningen Agricultural University. Netherland.
Huntingford F, Damsgard B. 2012. Fighting and Aggression. In: Huntingford F, Jobling M, Kardi S (eds.). Aquaculture and behavior. Wiley-BlackWell.A John Wiley \& Sons Ltd. Oxford (GB).

Ithurralde DR, Puerto G, Fernandez-Bornia F. 2014. Morphological development of Corydoras aff. Paleatus (Siluriformes, Callichthydae) and correlation with the emergence of motor and social behavior. Iheringia, Serie Zoologia 104: 189-199.

Kim SK, Jang IK, Seo HC, Cho YR, Samocha T. 2013. Effect of bioflocs on growth and immune activity of Pasific white shrimp, Litopenaeus vannamei postlarvae. Aquaculture Research: $1-10$.

[KKBK] Kementrian Koordinator Bidang Kemaritiman. 2017. Rencana Aksi Nasional Pembangunan Industri Ikan Hias 2017-2021. Jakarta. Indonesia : KKBK.

Liu G, Ye Z, Liu D, Zhao J, Sivaramasamy E, Deng Y, Zhu S. 2018. Influence of stocking density on growth, digestive enzyme activities, immune responses, antioxidant of Oreochromis niloticus fingerlings in biofloc systems. Fish and Shellfish Immunology 81: 416-422.

Long L, Yang J, Li Y, Guan C, Wu F. 2015. Effect of biofloc technology on growth, digestive enzyme activity, hematology, and immune response of genetically improved farmed tilapia Oreochromis niloticus. Aquaculture 448: 135-141.

Luo G, Liu G, Tan H. 2013. Effect of stocking density and food deprivation-related stress on the physiology ang growth in adult Scortum barcoo (McCulloch \& Waite). Aquaculture Research 44: 885-894

Luo G, Gao Q, Wang C, Liu W, Sun D, Li L, Tan H. 2014. Growth, digestive activity, welfare, and partial cost-effectiveness of genetically improved farmed tilapia Oreochromis niloticus cultured in a recirculating aquaculture system and an indoor biofloc system. Aquaculture 422-423: 1-7.

Magondu EW, Charo-Karisa H, Verdegem MCJ. 2013. Effect $\mathrm{C} / \mathrm{N}$ ratio levels and stocking density of Labeo victorianus on pond environmental quality using maize flour as a carbon source. Aquaculture 410-411: 157163.

Mahapatra BK, Dutta S. 2014. Breeding and rearing of an exotic ornamental catfish, Corydoras aeneus (Gill, 1858) in Kolkata, 
West Bengal and its economics. Proceeding of the Zoological Society 68: 159-163.

Maica PF, Murtado PS, Martins ACS, Filho KCM, Junior WW. 2018. Effect of alkalinity on food consumption of juvenile pacific white shrimp reared in clear water and biofloc system. Boletim do Instituto de Pesca 44: 1-9.

Manley CB, Rakocinski CF, Lee PG, Blaylock RB. 2014. Stocking density effect on aggressive and cannibalistic behaviors in larval hatcheryreared spotted seatrout Cynoscion nebulosus. Aquaculture 420-421: 89-94.

Mansour AT, Esteban MA. 2017. Effect of carbon sources and plant protein levels ini a biofloc system on growth performance, and the immune and antioxidant status of Nile tilapia Oreochromis niloticus. Fish and Shellfish Immunology 64: 202-209.

Perez-Fuentes JA, Hernandez-Vergara MP, PerezRostro CI, Fogel I. 2016. C:N ratios affect nitrogen removal and production of nile tilapia Orechromis niloticus raised in a biofloc system under high density cultivation. Aquaculture 452: 247-251.

Pinho SM, Molinari D, de Mello GL, Fitzsimmons KM. 2017. Effluent from a biofloc technology (BFT) tilapia culture on the aquaponics production of different lettuce varieties. Ecological Engineering 103: 146-153.

Poli MA, Schveitzer R, Nuner APO. 2015. The use of biofloc technology in a South American catfish Rhamdia quelen hatchery: Effect of suspended solids in the performance of larvae. Aquacultural Engineering 66: 17-22.

Poli MA, Legarda EC, Lorenzo MA, Martins MA, Vicira FN. 2019. Pasific white shrimo and nile tilapia integrated in biofloc system under different fish-stocking densities. Aquaculture 498: 83-89.

Qiao G, Zhang M, Li Y, Xu C, Xu DH, Zhao Z, Zang J, Li Q. 2018. Biofloc technology (BFT): An alternative aquaculture system for prevention of Cyprinid herpesvirus 2 infection in gibel carp (Carassius auratus gibelio). Fish and Shellfish Immunologi 83: 140-147.

Rocha AF, Filho MLB, Stech MR, Silva RP. 2017. Lettuce production in aquaponic and biofloc systems with silver catfish Rhamdia quelen. Boletim do Instituto de Pesca 44: 64-73.
Roques JAC, Schram E, Spanings T, Schaik T, Abbink W, Boerrigter J, Vries P, Vis H, Flik G. 2015. The impact of elevated water nitrite concentration on physiology, growth and feed intake of African catfish Clarias gariepinus (Burchell, 1822). Aquaculture Research 46: 1384-1395.

Santos FB, Esteves KE. 2015. A fish-based index of biotic integrity for the assessment of streams located in a sugarcane-dominated landscape in Southeastern Brazil. Environmental Management 56: 532-548.

Satora L, Koziol K, Zebrowski J. 2017. Squamous ephithelium formation ini the respiratory intestine of the bronze corydoras Corydoras aeneus (Callitchthyidae Teleostei). Acta Histochemica 5: 563-568.

Shiwanand A, Tripathi G. 2013. A review ammonia toxicity in fish. Asia Pacific Journal of Life Sciences 7: 193-232.

Schveitzer R, Arantes R, Baloi MF, Costodio PFS, Arana LV, Seiffert WQ, Andreatta. 2013. Effect of different biofloc leel on microbial activity, water quality and performance of Litopenaeus vannamei in atank system operated with no water exchange. Aquacultural Engineering 56: 59-70.

Souza-Bastos LR, Val AL, Wood CM. 2017. An Amazonian fish more sensitive to ammonia? Toxicity of ammonia to eleven native species. Hydrobiologia 789: 143-155.

Sutama GA, Sasanti AD, Taqwa FH. 2016. Rearing catfish (Pangasius sp.) with biofloc technology at different stocking density. Jurnal Akuakultur Rawa Indonesia 4: 200-215.

Tencatt LFC, Britto MR, Pavanelli CS. 2016. Revisionary of the armored catfish Corydoras paleatus (Jenyns, 1842) (Siluriformes, Callichthydae) over 180 years after its discovery by Darwin, with description of a new species. Neotropical Ichthyology 14: $1-20$.

Wang G, Yu E, Xie J, Yu D, Li Z, Luo W, Qiu L, Zheng Z. 2015. Effect of $\mathrm{C} / \mathrm{N}$ ratio on water quality in zero-water exchange tanks and the biofloc eksupplementation in feed on the growth performance of crucian carp, Carassius auratus. Aquaculture 443: 98-104.

Widanarni, Ekasari J, Maryam S. 2012. Evaluation of biofloc technology application 
on water quality and production performance of red tilapia Oreochromis sp. cultured at different stocking densities. Hayati Journal of Biosciences 19: 73-80.

Widanarni, Nurhayati D, Wahjuningrum D. 2013. Analysis of bacterial genetic diversity in biofloc aquaculture technology based on ARDRA 16S-rRNA gene. Jurnal Akuakultur Indonesia 12: 129-136.

Xi d, Zhang X, Lu H, Zhang Z. 2017. Caniballism in juvenile black rockfish, Sebastes schlegelii (Hilgendorf, 1880), rearing under controlled conditions. Aquaculture 479: 682-689.

Yusoff FM, Banerjee S, Khatoon H, Shariff M. 2011. Biological approaches in management of nitrogenous compounds in aquaculture systems. Dynamic Biochemistry, Process Biotechnology and Molecular Biology 5: 2131.

Zhang L, Xiong DM, Li B, Zhao ZG, Fang W, Yang K, Fan QX. 2012. Toxicity of ammonia and nitrite to yellow catfish (Pelteobagrus fulvidraco). Journal of Applied Ichthyology 28: 82-86.

Zhang N, Luo G, Tan H, Liu W, Hou Z. 2016. Growth, digestive enzyme activity and welfarr of tilapia (Oreochromis niloticus) in a bioflocbased system with poly- $\beta$-hydroxybutyric as a carbon source. Aquaculture 464: 710-717. 